\title{
Analysis of the healing process of the wounds occurring in rats using lasertherapy in association with hydrocolloid ${ }^{1}$
}

\author{
Shirley Santos Martins ${ }^{\mathrm{I}}$, Orlando Jorge Martins Torres ${ }^{\mathrm{II}}$, Orlando José dos Santos ${ }^{\mathrm{III}}$, Francisco de Assis Limeira Júnior ${ }^{\mathrm{IV}}$, Euler

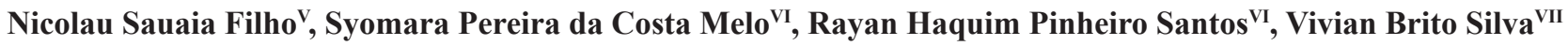

DOI: http://dx.doi.org/10.1590/S0102-865020150100000005

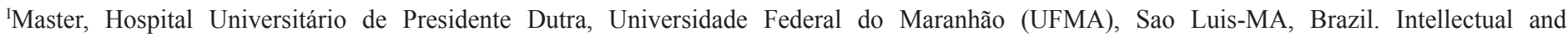
scientific content of the study, acquisition and interpretation of data.

${ }^{I I P h D}$, Associate Professor, Department of Medicine II, UFMA, Sao Luis-MA, Brazil. Conception, design, intellectual and scientific content of the study.

IIIPhD, Associate Professor, Department of Medicine II, UFMA, Sao Luis-MA, Brazil. Intellectual and scientific content of the study, critical revision. ${ }^{\text {IV }} \mathrm{PhD}$, Associate Professor, Department of Morphology, Universidade Federal da Paraíba (UFPB), Joao Pessoa-PB, Brazil. Acquisition of data.

${ }^{\mathrm{v} F e l l o w} \mathrm{PhD}$ degree, RENORBIO, Hospital Universitário de Presidente Dutra, UFMA, Sao Luis-MA, Brazil. Intellectual and scientific content of the study, acquisition and interpretation of data, manuscript writing.

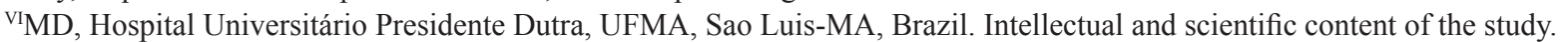

VIINurse, Hospital Universitário Presidente Dutra, UFMA, Sao Luis-MA, Brazil. Acquisition of data.

\section{ABSTRACT}

PURPOSE: To evaluate wound healing in rats by using low-level laser therapy (LLLT) associated with hydrocolloid occlusive dressing. METHODS: Forty male, adult, Wistar rats were used, distributed into four groups: LG (received $2 \mathrm{~J} / \mathrm{cm}^{2}$ of laser therapy); HG (treated with hydrocolloid); LHG (treated with $2 \mathrm{~J} / \mathrm{cm}^{2}$ of laser therapy and hydrocolloid); and the CG (treated with $1 \mathrm{~mL}$ of $0.9 \%$ saline). The wound was evaluated at pre-determined periods 3rd and 7th days, considering the macroscopic and histological parameters (inflammatory cells, capillary neoformation, fibroblasts, collagen formation and reepithelialization).

RESULTS: The LG group at seven days showed increased collagen formation, the LHG group at 3 days showed mild collagen formation. The HG group and the CG at 7 days showed complete reepithelialization.

CONCLUSION: Low-level laser therapy as well as the hydrocolloid dressing have favored the wound-healing process in rats.

Key words: Wound Healing. Laser Therapy, Low-Level. Rats. 


\section{Introduction}

The research of new technologies for the treatment of wounds facilitates the provision of patient care, decreasing length of stay, hospital costs as well as the aesthetic aspects of healing ${ }^{1-3}$.

One of the latest technologies is the low-level laser, which has characteristics to induce cell proliferation, increase the ATP synthesis, increase tensile strength of scar tissue and promoting the reduction of pain and trauma during dressing change $e^{4-8}$.

There are currently promising research aiming to substantiate the benefits of laser therapy as well as the occlusive dressing in moist environment in the systemic healing process of a wound ${ }^{4,6,7,9,10}$.

Thus the present study evaluated the effects of low-level laser associated with the hydrocolloid dressing on wound tissue repair in rats, by assessing the diameter of the wound and the histological analysis of healing.

\section{Methods}

The project was evaluated and approved by the Comite de Ética e Experimentação Animal do Centro de Ciências Agrárias da Universidade Estadual do Maranhão (UEMA) (Ethics and Animal Experimentation Committee of the Center for Agricultural Sciences, State University of Maranhão - UEMA), protocol $n^{\circ}$ 007/2009. The study followed the guidelines for animal research as set out by the Brazilian College of Animal Experimentation (COBEA). The study was conducted at the Laboratório da Liga Acadêmica de Cirurgia Experimental do Maranhão (LACEMA) (Experimental Surgery Laboratory of the Academic League of Maranhão - LACEMA).

The sample consisted of 40 male Wistar rats (Rattus norvegicus albinus, Rodentia mammalia), supplied by the UFMA vivarium. It was between 80 and 90 days old ( 83 days mean age). The weight was between $192 \mathrm{~g}$ and $270 \mathrm{~g}$ ( $250 \mathrm{~g}$ mean weight). They were kept in groups of five per standard cage for the species where the light-dark cycle was 12 hours and humidity was the same as a normal environment without any artificial regulation. The temperature was constant at $20 \pm 2{ }^{\circ} \mathrm{C}$. The animals were fed on standard commercial food and had free access to water throughout the experiment.

The animals were randomly divided into four groups of ten (10) rats:

1. Laser therapy group (LG) used single daily application of $50 \mathrm{~J} / \mathrm{cm}^{2}(2 \mathrm{~J})$ of irradiation to the lesion;

2. Hydrocolloid Group (HG) used hydrocolloid occlusive dressing $2 \mathrm{~cm}^{2}$ larger than the lesion;

3. Laser therapy with hydrocolloid group (LHG) used single application of $50 \mathrm{~J} / \mathrm{cm}^{2}(2 \mathrm{~J})$ of daily laser irradiation punctually to the lesion and was occluded with hydrocolloid occlusive dressing $2 \mathrm{~cm}^{2}$ larger than the lesion;

4. Control group (CG) used irrigation with $1 \mathrm{~mL}$ of $0.9 \%$ saline.

These groups were redistributed into two subgroups of five animals and denominated subgroup LG3 and LG7, HG3 and HG7, LHG3 and LHG7 and CG3 and CG7 according to the days of death (3rd and 7th postoperative days), respectively.

Epilation in the dorsal region in a $4-\mathrm{cm}^{2}$ area was performed after anesthesia. The skin was marked at the area center with metal "punch" of $0.7 \mathrm{~mm}$ diameter and a fragment was removed approaching to the dorsal muscle fascia.

The low-level laser therapy system used in tissue repair was a model of MM OPTICS LTD, pen type, powered by electrical voltage, emission of diode low-level laser in visible spectrum $(660 \mathrm{~nm})$, with output power of $40 \mathrm{~mW}$ and $\varnothing 0.04 \mathrm{~cm} 2$. During laser application, safety glasses with special deposition lens to attenuation of visible laser light and energy density of $50 \mathrm{~J} / \mathrm{cm}^{2}$ (2J) were used.

The hydrocolloid occlusive dressing used was composed of carboxymethylcellulose absorbent particles, encapsulated in an elastic and adhesive synthetic dough of polyurethane, flexible, permeable to oxygen and moisture vapor. (Figure 2). Each animal was subjected to anesthesia with $2 \%$ xylazine hydrochloride $(5 \mathrm{mg} /$ $\mathrm{kg} \mathrm{MI})\left(\mathrm{Kensol}^{\circledR}\right)$ and 5\% ketamine hydrochloride $(22 \mathrm{mg} / \mathrm{kg}, \mathrm{IM})$ $\left(\right.$ Vetanarcol ${ }^{\circledR}$ ) combined in the same syringe.

The animals were submitted to daily clinical assessment and observed regarding the acceptance of food, surgical wound and death. In those animals in which hydrocolloid dressings with and without application of low-level laser (LLLT) were used, exchanges were performed every 12 hours to maintain the dressing attached to the lesions for 24 hours, the other groups without occlusive dressing underwent daily application of the corresponding treatment to each group. The wound was daily measured in the major and minor axis with disposable millimetric ruler.

The animals were killed by a lethal dose of $2 \%$ xylazine $(20 \mathrm{mg} / \mathrm{kg}, \mathrm{IM})$ and $5 \%$ ketamine hydrochloride $(30 \mathrm{mg} / \mathrm{kg}$, IM) in the predetermined days of death for each subgroup. The removed surgical parts were preserved in $10 \%$ formalin and stained with hematoxylin-eosin (HE) for full evaluation of tissue sections, and Masson's Trichrome (MT), to evaluate findings of existing collagen fibers at sites of interstitial fibrosis.

For data analysis of the wound size the analysis of variance (ANOVA) was used, followed by the Tukey test. For the analysis of the histological variables results nonparametric Kruskal Wallis test was used, followed by Dunn's test. The level of significance was set at $\mathrm{p}<0.05$. 


\section{Results}

There was no significant difference in the average size of the wounds among the groups of three days. However there was a statistically significant difference among the groups of seven days treated with saline only (CG), which showed the smallest area compared to the other groups. The mean diameter of the wound in LG and LHG groups was lower than in HG group (Table 1 and Figure 1).

TABLE 1 - Mean and standard deviation of the size of wound on the 3rd day after injury induction (number 3 ) and mean and standard deviation on the $7 \mathrm{rd}$ (number 7 )

\begin{tabular}{ccc}
\hline Group - Day & Mean & Tukey \\
\hline GH - 3 & $0.72 \pm 0.002$ & $\mathrm{a}$ \\
GL - 3 & $0.7 \pm 0.00$ & $\mathrm{a}$ \\
GC - 3 & $0.7 \pm 0.00$ & $\mathrm{a}$ \\
GLH -3 & $0.7 \pm 0.00$ & $\mathrm{a}$ \\
GH - 7 & $0.60 \pm 0.00$ & $\mathrm{a} *$ \\
GL - 7 & $0.50 \pm 0.00$ & $\mathrm{~b}$ \\
GC - 7 & $0.42 \pm 0.05$ & $\mathrm{c} *$ \\
GC - 7 & $0.50 \pm 0.07$ & $\mathrm{~b}$
\end{tabular}

a, c - Different letters mean $\mathrm{p}<0.05$ by Tukey test

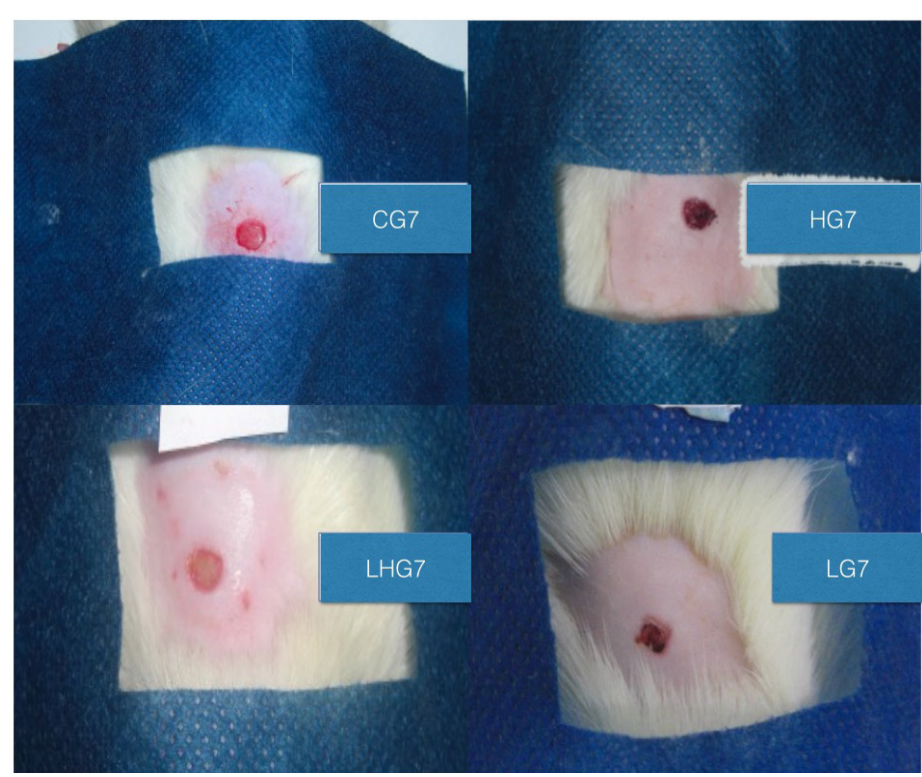

FIGURE 1 - Representative image of wound healing in groups in seven days.

The results showed there was no significant difference among the groups of three days regarding the acute inflammatory process. However, LG and HG groups of seven days showed chronic inflammatory process different from the CG and LHG of seven days, which showed acute processes (Table 2).

Capillary neoformation was discreet in LG3, LHG3, HG3 groups, except for the CG3 group where it was absent. However in the LG7 group it was discreet and in the other groups (CG7, LHG7, HG7), moderate (Table 2).

TABLE 2 - Classification of histological variables and the results of Dunn's test.

\begin{tabular}{|c|c|c|c|c|c|}
\hline \multirow[b]{2}{*}{ Day } & \multirow[b]{2}{*}{ Findings } & \multicolumn{4}{|c|}{ Group } \\
\hline & & $\mathrm{HG}$ & LG & $\mathrm{CG}$ & LHG \\
\hline \multirow{5}{*}{3} & Inflammation & Acute & Acute & Acute & Acute \\
\hline & Fibroblast proliferation & Discrete & Discrete & Discrete & Discrete \\
\hline & Collagenization & Absent & Absent & Absent & Discrete \\
\hline & Reepithelization & Absent & Absent & Parcial $^{\mathrm{a}}$ & Absent $^{\mathbf{b}}$ \\
\hline & Neovascularization & Discrete $^{b}$ & Discrete $^{\mathbf{b}}$ & Absent $^{\mathrm{a}}$ & Discrete $^{b}$ \\
\hline \multirow{5}{*}{7} & Inflammation & Chronic & Chronic & Acute & Acute \\
\hline & Fibroblast proliferation & Moderate & Moderate & Moderate & Moderate \\
\hline & Collagenization & Discrete $^{\mathbf{b}}$ & Accented $^{\mathrm{a}}$ & Discrete $^{\mathbf{b}}$ & Discrete $^{b}$ \\
\hline & Reepithelization & Complete ${ }_{-}^{\mathrm{a}}$ & Partial & Complete $^{\mathrm{a}}$ & Partial \\
\hline & Neovascularization & Moderate & Discrete $^{\mathbf{a}}$ & Moderate & Moderate \\
\hline
\end{tabular}

*a, b - Different letters mean $\mathrm{p}<0.05$ by Dunn's test 
There was no significant variation among the groups regarding the proliferation of fibroblasts. It was discreet in the groups of three days and moderate in the groups of seven days (Table 2).

Reepithelization occurred partially in CG group of three days and was absent in the other groups (LG3, LHG3, HG3). However on the seventh day it was complete in $\mathrm{HG}$ and $\mathrm{CG}$ groups, being partial in the other groups of this period (LG7, LHG7).

The LHG group of three days shows a slight collagen formation (Figure 1), unlike the other groups, which were absent in this aspect. However pronounced collagen formation was observed in LG group of seven days, being it discreet in the other groups (Figures 2 to 4 ).

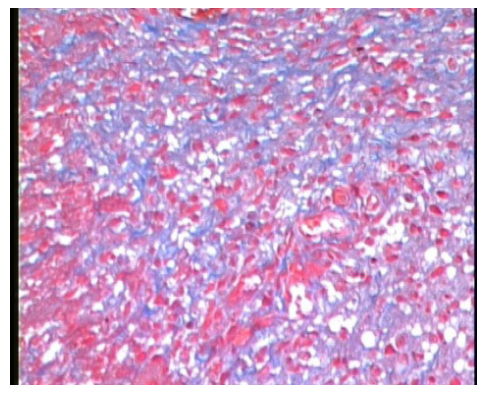

FIGURE 2 - Representative image of collagen beams LHG 3 days (x10 magnification).

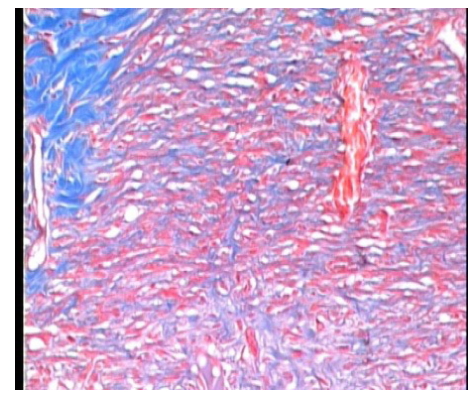

FIGURE 3 - Representative image of collagen beams LG 7 days (x10 magnification).

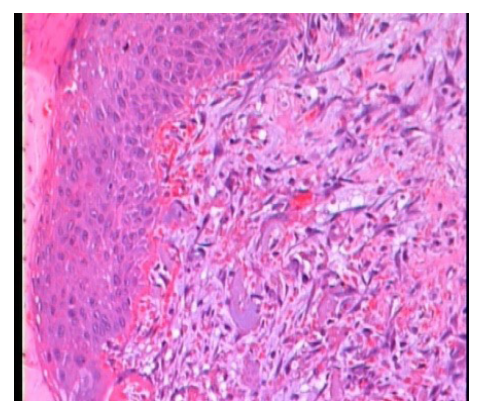

FIGURE 4 - Representative image of collagen beams HG 7 days (x10 magnification).

\section{Discussion}

The healing suffered interference next to the wound boundaries when hydrocolloid dressing was used, since this adhesive pulled the animal skin during the exchange, which occurred twice a day; thus, configuring the finding of higher wound size for the HG group and lower for the other groups (CG, LG. LHG). The LHG and LG groups kept the same average size, suggesting possible effect of LLLT on the elements of wound contraction.

Studies using LLLT showed no similarities due to changes in methodology due to differences in implemented radiation ${ }^{7}$.

Study on wounds that have undergone laser radiation shows they become less edematous, suggesting anti-inflammatory effect by LLLT; however, anti-inflammatory action in groups treated with laser was not demonstrated in this study. It was observed that the animals that received laser application associated or not with the hydrocolloid dressings were more calm, suggesting an analgesic effect of the therapy ${ }^{11}$.

Regarding the anti-inflammatory effects of the laser, the interference in the synthesis of prostaglandins is emphasized, so the LLLT used can produce analgesia ${ }^{10,12}$.

The therapeutic effects of the laser on the different biological tissues are demonstrated in both in vitro and in vivo studies, especially the studies that report increase in local microcirculation, reduction of the number of inflammatory cells, analgesic effects, stimulation of epithelial cell and fibroblasts proliferation, as well as increased collagen synthesis ${ }^{6,7,9,10,13}$.

The results of this study differ from other studies that demonstrate increased neovascularization and fibroblast proliferation in lesions treated with lasertherapy, but are similar in evaluating collagen formation. Although there is contradiction in results on the effects of lasertherapy on cell proliferation, several studies demonstrate that despite the variation of the dose and wavelength, the laser light is a beneficial adjunct therapy in tissue repair ${ }^{7}$.

The complete re-epithelialization evidenced by microscopic evaluation in $\mathrm{HG}$ and CG was not macroscopically observed in the study period. It is necessary an analysis on a longer period of time, culminating in the remodeling phase of the wound and visualization of the epidermis formation.

Most studies on laser action in tissue repair were performed in animal models. However, the same findings reported in studies in vitro and in animals are suggested by studies in humans ${ }^{9,14}$. 
The indication of topical therapy of lesions with occlusive dressing to keep the humidity has proven and established action in the scientific context, as it keeps the ideal moisture and temperature for the promotion of mitotic cells action, analgesia and debridement ${ }^{8,15}$.

No experimental study associating laser therapy with occlusive dressing to keep the wound environment moist like hydrocolloid was observed in the literature. Thus, further research is needed to analyze and better understand the effectiveness of both in the wound healing process.

\section{Conclusion}

Low-level laser therapy as well as the hydrocolloid dressing have favored the wound-healing process in rats.

\section{References}

1. Ailinger RL. Contributions of qualitative research to evidencebased practice in nursing. Rev Latinoam Enferm. 2003;11(3):275-9. PMID: 12958629.

2. Ferreira E, Lucas R, Rossi LA, Andrade D. Treatment of the burned patient: a re-view of the literature. Treatment of the burned patient: a review of the literature. Rev Esc Enferm USP. 2003;37:44-51. PMID: 12968429.

3. Oliveira SHS, Soares MJGO, Rocha PS. Use of collagen and aloe vera in ischemic wound treatment: study case. Rev Esc Enferm USP. 2010;44(2):346-51. PMID: 20642045.

4. Gál P, Vidinský B, Toporcer T, Mokrý M, Sabo J, Mozeš Š, Longauer F. Histolog-ical assessment of the effect of laser irradiation on skin wound healing in rats. Photomed Laser Surg. 2006;24(4):480-8. PMID: 16942428.

5. Pugliese LS, Medrado AP, Reis SRA, Andrade ZA. The influence of low-level laser therapy on biomodulation of collagen and elastic fibers. Pesq Odontol Bras. 2003;17(4):307-13. PMID: 15107911.

6. Demidova-Rice TN, Salomatina EV, Yaroslavsky AN, Hamblin MR, Herman IM. Low-level light stimulates excisional wound healing in mice. Lasers Surg Med. 2007;39(9):706-15. PMID: 17960752.

7. Andrade FSSD, Clark RMO, Ferreira ML. Effects of low-level laser therapy on wound healing. Rev Col Bras Cir. 2014;41(2):129-33. PMID: 24918727.

8. Franco D, Gonçalves LF. Skin wounds: adequate dressing choice. Rev Col Bras Cir. 2008;35(3):203-6. doi: 10.1590/S010069912008000300013

9. Kajagar BM, Godhi AS, Pandit A, Khatri A. Efficacy of low level laser therapy on wound healing in patients with chronic diabetic foot ulcers - A randomised control trial. Indian J Surg. 2011;74(5):35963. PMID: 24082586.

10. Garcia VG, MacArini VC, De Almeida JM, Bosco AF, Nagata MJH, Okamoto T, Longo M, Theodoro LH. Influence of low-level laser therapy on wound healing in nicotine-treated animals. Laser Med Sci. 2012;27(2):437-43. PMID: 21750957.

11. Tatarunas AC, Matera JM, Dagli MLZ. Estudo clínico e anatomopatológico da cicatrização cutânea no gato doméstico: utilização do laser de baixa potência GaAs (904 nm). Acta Cir Bras. 1998;13(2):86-93. doi: 10.1590/S0102-86501998000200004.

12. Garcia VG, Lima MA, Okamoto T, Milanezi LA, Junior EC,
Fernandes LA, Almeida JM, Theodoro LH. Effect of photodynamic therapy on the healing of cu-taneous third-degree-burn: histological study in rats. Lasers Med Sci. 2010;25(2):221-8. PMID: 19533211.

13. Hodjati H, Rakei S, Johari HG, Geramizedeh B, Sabet B, Zeraatian S. Low-level laser therapy: an experimental design for wound management: a case-controlled study in rabbit model. J Cutan Aesthet Surg. 2014;7(1):14-7. PMID: 24761093.

14. Hopkins JT, McLoda TA, Seegmiller JG, Baxter GD. Low-level laser therapy facil-itates superficial wound healing in humans: a triple-blind, sham-controlled study. J Athl Train. 2004;39(3):223-9. PMID: 15496990.

15. Jones ML. An introduction to absorbent dressings. Br J Community Nurs. 2014 Dec;Suppl Wound Care:S28-30. doi: 10.12968/ bjen.2014.19. 15 .

\section{Correspondence:}

Orlando José dos Santos Departamento de Medicina II, ILA

Faculdade de Medicina, Universidade Federal do Maranhão

Avenida Gonçalves Dias, 21

65020-240 São Luis-MA Brasil

orlanddojs@hotmail.com

Received: Jun 17, 2015

Review: Aug 18, 2015

Accepted: Sep 18, 2015

Conflict of interest: none

Financial source: FAPEMA

${ }^{1}$ Research performed at Laboratório da Liga Acadêmica de Cirurgia Experimental do Maranhão (LAB-LACEMA), Department of Medicine II, ILA, School of Medicine, Universidade Federal do Maranhão (UFMA), Sao Luis-MA, Brazil. 